\title{
Hermann Vinterberg og C. A. Bodelsen: Dansk- engelsk Ordbog 3. udgave. Redaktion: Viggo Hjørnager Pedersen. Gyldendal, 1990
}

\section{Résumé}

Vinterberg and Bodelsen's Danish-English dictionary has now been published in its third, revised edition. As a natural consequence of the development in society as a whole, Danish and English usage has changed considerably since the second edition was published in the mid-1960s, thousands of new words have been added to both languages, and a range of words and expressions have undergone a change in meaning. The present review focusses on seeing whether these changes are reflected in the selection of entries and the translation equivalents offered in the dictionary and concludes that, even though there are about 100,000 changes (of which approximately 50,000 are additions) in the new edition, a wide range of entries are not sufficiently updated. Given the development in computer software and lexicography within the last two decades, it must be concluded that the dictionary is not on the forefront of the development.

Endelig kom den længe ventede 3. udgave af Vinterberg og Bodelsen. I de 25 år, der er gået siden udgivelsen af den forrige udgave, har sprogbrugen ændret sig på flere områder, og såvel dansk som engelsk har fået tilføjet et hav af nye ord og vendinger som naturlig konsekvens af udviklingen inden for alle områder af samfundet. Når man skal foretage en vurdering af den nye udgave, er det derfor nødvendigt at se, hvorledes dette afspejler sig i den største eksisterende dansk-engelske ordbog.

Ifølge forord og pressemeddelelse er der i den nye udgave 230.000 opslagsord, heraf 120.000 udtryk og vendinger, på i alt 1476 sider. I forhold til andenudgaven skulle der være foretaget omkring 100.000 ændringer, heraf godt halvdelen som tilføjelser.

Stadig ifølge pressemeddelelsen skulle der være gjort "meget ud af at revidere eksemplerne på engelsk talesprog og på oversættelserne af faste udtryk og vendinger". Andre end jeg har allerede påpeget at man ikke med hjælp fra den nye ordbog kan lagge sig i baghjulet af (den teknologiske udvikling), eller vare på forkant (med udviklingen), jvf. bl.a. Helge Schwarz anmeldelse i Sprint (1, 1991); man kan heller ikke (følge den nyeste) trend (inden for et område), få informationer om de nyeste tiltag, eller faxe besked om dem til sine kolleger. Slår man trend op, får man ( $i$ 
vavning) warp. Ingen nye udviklingstendenser. Det er klart, at ikke alt kan være med selv i en ordbog af Vinterberg og Bodelsens omfang; men det er ikke svært at finde eksempler på moderne sprogbrug / nye ord og vendinger, som ikke er repræsenteret $\mathrm{i}$ ordbogen.

Det er til gengæld vanskeligt at få øje på en klart defineret politik med hensyn til, hvad der er medtaget, og hvad der er udeladt i ordbogen. For ikke at bygge vurderingen helt på arbitrære eksempler, har jeg valgt at lade mine ordbogsopslag inspirere af en bestemt avisartikel, EF-Union på menuen, i Morgenavisen Jyllands-Postens tillæg Det nye EUROPA (5. maj 1991). Forlagets pressemeddelelse hævder, at der er gjort "en hel del ud af oplysninger om sprogbrugen inden for EFs institutioner", så lad os se på det.

Starter man uskyldigt med at slå $E F$ op, får man (fk. de Europaiske Fallesskaber) EC (fk. the European Communities) (NB i reglen bruges (the) $E E C$, $c f . E \emptyset F$ ). I EFs egne publikationer ses som oftest European Community, altså entalsform, mens der i andre engelsksprogede tekster ses både entals- og flertalsform: the European Community eller Соттиnities. Ordbogen burde angive begge former både her og under faellesskab, hvor man kan slå De europasike Fallesskaber op, igen med oversættelse til flertalsform the European Communities. Hvad angår forkortelserne, synes det rigtigt, at engelsk anvender såvel $E C$ som $E E C$, men dansk næsten udelukkende benytter $E F$.

Slår man derefter $E F$-union op, er man på den. Man kan finde en $E F$ tilhoenger og en EF-modstander, men ingen EF-union, og heller ikke $E F$-parlamentet, EF-traktaten, eller EF-kommissionen. Hvis man i sin søgen efter EF-parlamentet kigger under Europa-parlamentet, får man dog ganske rigtigt the European Parliament og lige ved siden af Europarådet (the Council of Europe); men ser man i stedet under parlament, får man at vide, at det i britiske lande hedder Parliament og (EF ogs.) (the) Assembly, hvoraf det sidste ikke synes at være i overensstemmelse med nutidig terminologi. EF-traktaten må man selv konstruere ved under traktat at finde treaty eller slå op under Romtraktaten og finde $(E F)$ the Treaty of Rome, men man finder ikke hjælp til oversættelsen af traktatudkast eller at traktatfaste (samarbejdet). EF-kommissionen finder man under kommission: (EF) the Commission, herunder også formanden for Kommissionen: (EF) the President of the Commission.

Men EF-unionen og (en samlet) unionspakke er stadig hængepartier. Slår man op under union, er der ingen henvisning til EF, men derimod til the Union of Kalmar. Ser man under europaisk(e), får man stadig ingen 
referencer til EF, ingen europaisk union, men derimod bl.a. det europaiske atomenergifallesskab (the European Atomic Energy Community), europaisk berømt (of European reputation) og det europaiske kul- og stalfallesskab (the European Coal and Steel Community), og forsøger man at finde frem til unionen via monetar, politisk, eller $\phi k o n o m i s k$, får man nok EF-referencer, men stadig ingen union. Under Europa som opslagsord får man til gengæld $(=E F)$ Europe, the Common Market, the EEC.

Forsøger man sig nu med EF-formandsskab, finder man under formandsskab presidency (the presidency of the Economic Council) uden henvisning til EF; endvidere optræder i det efterfølgende - med henvisning til EF - formandsskabet $i$ et udvalg (the Bureau of a committee) samt formandskomité og formandsudvalg, der oversættes til henholdsvis (EF) The Presidential Committee og (EF) the Committee of Presidents. Ikke blot jeg, heller ikke EF-Kommissionens dokumentationscenter i København, mener at have hørt om disse to sidstnævnte gremier.

Så prøver vi medlemsland(e). Der er masser af medlems-, men ingen -lande. Til gengæld kan man slå Ministerrådet op og finde (the) Council of Ministers.

Hvad angår EF-terminologien, må man altså konkludere, at der nok er mange termer med i ordbogen, men de er ikke alle lige pålidelige, og man må derfor checke andre kilder for at sikre sig den korrekte oversættelse af en given term; helt gængse og overordnede betegnelser i EF-sammenhæng er til tider svære at finde og flere findes ganske simpelt hen ikke. Selv om termen ikke forekommer i "min" tekst, kan jeg ikke lade være med at nævne, at det indre marked kun kan slås op under enhedsmarked med oversættelsesækvivalenten single market og uden angivelse af EF som emneområde.

Hvis vi stadig holder fast i artiklen fra Jyllands-Posten, kan vi forsøge os med andre substantiver og substantivkomposita. Hvad angår (opskriften på en ny europaisk) gryderet, kan vi bruge oversættelsen casserole, til råskitse en rought sketch eller rough outline; og en oversættelse af udenrigspolitik, forsvar og mønt (i betydningen currency) er også umiddelbart tilgængelig. Derimod kan man hverken finde regeringskonference under regerings- eller konference; stormagt bliver oversat som Great Power (med versaler) samt (isar om USA of USSR) superpower, hvor sidstenævnte forekommer at være den mest gængse engelske ækvivalent. $E C U$ finder vi i ordbogen, ligeså $D$-mark. Men hvad angår sidstnævnte påstås denne at hedde det samme på engelsk eller eventuelt 
deutsch $\underline{\mathbf{e}}$ mark, hvilket dels er mod mine fornemmelser, dels er imod Longman Dictionary of Contemporary English, der ikke har D-mark, men derimod mark: a German unit of money med henvisning til Deutschmark (uden e!), der også kan skrives Deutsche Mark (med e). Når vi kommer til vetoret med oversættelsen (right of) veto, udviklingshjaelp/-bistand med oversættelsen (EF) development aid (el. assistance), genforening med oversættelsen reunion; reunification og eksemplet German reunification er vi bedre hjulpet. Det samme gælder, når vi søger oversættelse af indvandrer, flygtning (selv om eksemplet taler om refugees from the Spanish Civil War), visum og nedrustning. Man skal selv konstruere en oversættelse af våbenproduktion og våbenspredning, men det kan jo også lade sig gøre. Våbenkontrol oversættes som arms control, og topmфde som summit (meeting). Når vi kommer til den indtil for nylig hendøende forsvarsorganisation, Vestunionen, er vi på den igen. Vestunionen finder vi ikke, og det kan i nogen grad undre, fordi der synes at være så mange europæiske organisationer og sammenslutninger af meget forskellig observans med i ordbogen, specielt dem, som har nogle år på bagen. Under søgningen efter Vestunionen, finder vi til gengæld Vestvolden med oversættelsen (hist.: 1940-45) the West Wall; netop denne glose er et godt eksempel på det ganske omfattende ordforråd fra 2. Verdenskrig, som har fået lov til at overleve i den nye ordbog. Det gælder for eksempel også en hipo/hipomand, der ikke oversættes, men derimod forklares på engelsk til benefice for den ikke-dansktalende læser: [member of the German auxiliary police recruited among Danish collaborators during the Occupation]; the Occupation forklares dog ikke nærmere, og det er op til den oplyste læser selv at konkludere, at der er tale om den tyske besættelse af Danmark 1940-45.

Vender vi os herefter til verberne og disses kollokationer samt andre faste udtryk med verbum og substantiv i teksten, finder vi bl.a. enter som oversættelse af at trade ind $i$ (en EF-union); fall to the ground; fall flat som oversættelse af falde til jorden (under jord [forb. med prap.]); be on the point of som oversættelse af vare pa nippet til (under nip).

Derimod er udestå som transitivt verbum (der udestår stadig problemer på de mest følsomme områder) ikke med, kun det intransitive, der oversættes som remain unpaid. Der er flere kollokationer, som forekommer let bedagede under opslagsordet kur; men man finder ikke be on a diet, der ville passe fortrinligt i sammenhængen de svage EF-medlemmer skal på kur for at blive sunde nok til at lege på lige fod med de stcerke. Under front kan man bl.a. finde face (the enemy; an opponent) 
som oversættelse til gфre front mod; der er derimod ikke nogen hjælp at hente til oversættelse af at gøre falles front mod (en fremtid, som ...), og en ækvivalent til vove den påstand/vove påstanden at findes hverken under vove eller påstand.

Med den nye Vinterberg og Bodelsen som eneste hjælpemiddel kommer man, som det fremgår af ovenstående, alt for ofte ud i svære problemer, når man skal oversætte en moderne avistekst. Ifølge forlaget er ordbogen "et uundværligt arbejdsredskab for professionelle oversættere, undervisere og sprogstuderende" (pressemeddelelsen); det kan ikke bestrides. Men vi kan til gengæld slet ikke nøjes med Vinterberg og Bodelsen; hertil er hullerne i det moderne ordforråd alt for store. Jeg tror, vi er mange, der gerne havde set, at der var strøget en langt større række ældre ord og vendinger i 3. udgaven til fordel for nogle mere moderne; der er jo stadig de gamle andenudgaver på hylden (eller biblioteket), hvis man skal oversætte ældre tekster.

Hvis man ser på de ord og vendinger, der er specifikt danske og derfor ikke umiddelbart har en engelsk ækvivalent, er det lidt forskelligt, hvor godt man er hjulpet med ordbogen. Et fortærsket eksempel som rødgr $\phi d$ forsynes ligesom i 2. udgave med forklaringen [a kind of thickened red fruit juice], der er unødvendig for en dansker, og som ikke gør en englænder ret meget klogere. Til gengæld får vi television news for $T V$-avis, og det er da ikke så skævt, som vi siger i Jylland. Handelshøjskole oversættes som commercial college, hvilket ingen af handelshøjskolerne selv gør; og Handelshøjskolerne i København og Århus forsynes med forældede engelske betegnelse, og ikke dem, som højskolerne selv bruger i dag, nemlig henholdsvis the Copenhagen Business School og the Aarhus School of Business; cand.ling.merc. og cand.interpret. forklares ligesom Dankort på engelsk, men uden en oversættelse, hvilket forekommer helt rimeligt, da der ikke er nogen direkte oversættelsesækvivalenter til sådanne termer. Men man kan måske undre sig over, hvorfor opslagsordene overhovedet er med. Ordbogen har generelt en klar dansk-til-engelsk orientering; alle forklaringer i tegn- og forkortelseslisten er på dansk (nogle, men ikke alle er oversat til engelsk) og forklaringer i selve ordbogsartiklerne er også på dansk. En engelsktalende bruger har ikke mange chancer, hvis vedkommende ikke allerede er ganske velbevandret i dansk. Han eller hun kan måske så til gengæld have glæde af de engelske forklaringer til de specifikt danske opslagsord som $r \phi d g r \phi d$ og Dankort. 
Hvad angår grammatiske oplysninger, indskrænker ordbogen sig til ordklasseangivelse på dansk af opslagsord, hvor det skønnes nødvendigt (?); dette gælder dog kun hovedopslagsordene og f.eks. ikke komposita. Her ud over er der ingen grammatiske oplysninger; da det (som det fremgår af ovenstående) også er sparsomt med kollokationer, og de få eksempler generelt ikke er sat ind i en kontekst (som f.eks. (del af) en sætning), er meget overladt til den kompetence, som brugeren måtte have i forvejen, subsidiært kan efterkontrollere i andre, mere brugervenlige (engelsk-engelske) ordbøger.

Stilniveau angives kun, hvis der er tale om $\mathrm{T}$ (talesprog) eller $\mathrm{S}$ (slang); mere differentierede angivelser ville hjælpe mange ordbogsbrugere, og tydeligere stilangivelser må derfor også på listen over ønsker til næste udgave.

Emneområde angives ved de enkelte lemmata, dog ikke ganske konsekvent. Af ovenstående er det fremgået, at EF-termer optræder dels med, dels uden angivelser som sådanne. Selv om emneområdet tandl. eksisterer i ordbogen, er caries klassificeret som med. (medicinsk) terminologi; cellekultur har ingen angivelse af emneområde, det har til gengæld cellekerne (biol.) og celleprøve (med.). Det kan for den uindviede læser (oversætter) være svært at se, om denne forskel i de tre komposita med celle-skyldes en vilkårlighed i angivelserne, eller der er en fagforskel, som man ikke har fattet.

Med den udvikling, der har fundet sted inden for leksikografien i de seneste år, kan det undre, at dette ikke afspejler sig i et af Gyldendals flagskibe som Vinterberg og Bodelsens ordbog. Man må håbe, at redaktionen af fjerdeudgaven (snart!) vil få stillet moderne og tidsbesparende teknologi til rådighed, så man kan koncentrere sig om at forbedre kvaliteten af selve ordbogen på afgørende punkter som de ovenfor nævnte. Om tredieudgaven må jeg med dronning Victoria konkludere, at "We are not amused". Den befinder sig hverken sig på forkant med eller i baghjulet af den nyeste udvikling. Vi skal forhåbentlig ikke vente 25 år på en ny og fjerde udgave af Gyldendals store røde ordbog. 